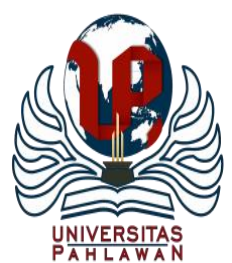

Jurnal Abdidas Volume 2 Nomor 6 Tahun 2021 Halaman 1321 - 1326

JURNAL ABDIDAS

http://abdidas.org/index.php/abdidas

\title{
Pelatihan Pembuatan Perangkap Serangga pada Kelompok Wanita Tani Suka Maju Kelurahan Malumbi
}

\author{
Yonce Melyanus Killa ${ }^{1}$, Uska Peku Jawang ${ }^{2}$, Marten Umbu Nganji ${ }^{3}$, Lusia Danga Lewu ${ }^{4}$, \\ Melycorianda H. Ndapamuri ${ }^{5}$, Suryani K. K. L. Kapoe ${ }^{6}$ \\ Agroteknologi, Universitas Kristen Wira Wacana, Sumba, Indonesia ${ }^{1,2,3,4,5,6}$ \\ E-mail : yonce@unkriswina.ac.id ${ }^{1}$, uska@unkriswina.ac.id ${ }^{2}$, martenngannji@unkriswina.ac.id ${ }^{3}$, \\ lusia@unkriswina.ac.id ${ }^{4}$,melycorianda@unkriswina.ac.id ${ }^{5}$, suryani@unkriswina.ac.id ${ }^{6}$
}

\begin{abstract}
Abstrak
Kelompok Wanita Tani (KWT) Suka Maju merupakan salah satu kelompok tani yang ada di Kelurahan Malumbi Kecamatan Kambera Kabupaten Sumba Timur yang melakukan kegiatan pertanian kususnya dibidang hortikultura. Kegiatan pertanian yang dilakukan sering terjadi masalah salah satunya dari organisme pengganggu tanaman (OPT) sehingga membutuhkan pengetahuan untuk melindungi tanaman yang dibudidayakan. Kegiatan pengabdian kepada masyarakat ini bertujuan untuk mengenalkan teknik pengendalian hama terutama serangga yang ramah lingkungan dan menggunakan bahan bekas. Metode kegiatan yaitu Sosialisasi, Ceramah Praktek pembuatan perangkap kuning dan memasang perangkap di lahan serta monitoring. Hasil sosialisasi menunjukan anggota kelompok tani paham dan dapat membedakan OPT dan dapat membuat perangkap kuning dari bahan bekas dan mampu membuat perangkap kuning dan mengaplikasikan atau memasangnya pada lokasi lahan budidaya. Hasil monitoring ditemukan beberapa serangga yang terperangkap atau lengkep pada perangkap kunung seperti lalat buah (Bactrocera sp.) dan imago dari ulat crop (Plutella xylostela) serta beberapa serangga lain.
\end{abstract}

Kata kunci: KWT Suka Maju, perangkap kuning

\section{Abstract}

The Suka Maju Women Farmers Group (KWT) is one of the farmer groups in Malumbi Village, Kambera District, East Sumba Regency which carries out agricultural activities especially in the field of horticulture. Agricultural activities carried out often have problems, one of which is from plant pest organisms (OPT) so that knowledge is needed to protect cultivated plants. This community service activity aims to introduce pest control techniques, especially insects that are environmentally friendly and use used materials. The method of activity is Socialization, Lectures on the Practice of making yellow traps and setting traps on the land as well as monitoring. The results of the socialization show that members of the farmer group understand and can distinguish pests and can make yellow traps from used materials and can make yellow traps and apply or install them on cultivated land locations. The monitoring results found that several insects were trapped or attached to the yellow trap, such as fruit flies (Bactrocera sp.) and imago of crop caterpillars (Plutella xylostela) as well as several other insects.

Keywords: KWT Suka Maju, yellow trap

Copyright (c) 2021 Yonce Melyanus Killa, Uska Peku Jawang, Marten Umbu Nganji, Lusia Danga Lewu, Melycorianda H. Ndapamuri, Suryani K. K. L. Kapoe

$\triangle$ Corresponding author

Address : Universitas Kristen Wira Wacana

Email : yonce@unkriswina.ac.id

ISSN 2721- 9224 (Media Cetak)

DOI : https://doi.org/10.31004/abdidas.v2i6.476

ISSN 2721- 9216 (Media Online) 
1322 Pelatihan Pembuatan Perangkap Serangga pada Kelompok Wanita Tani Suka Maju Kelurahan Malumbi - Yonce Melyanus Killa, Uska Peku Jawang, Marten Umbu Nganji, Lusia Danga Lewu, Melycorianda H. Ndapamuri, Suryani K. K. L. Kapoe

DOI: https://doi.org/10.31004/abdidas.v2i6.476

\section{PENDAHULUAN}

Kelompok Wanita Tani (KWT) Suka Maju merupakan salah satu kelompok tani yang ada di Kelurahan Malumbi Kecamatan Kambera Kabupaten Sumba Timur. Kegiatan budidaya pertanian dari kelompok tani wanita ini kususnya dibidang hortikultura. Tanaman-tanaman yang sering ditanami oleh anggota kelompok ini seperti bawang merah, tomat, cabai, paria, kubis, sawi dan kangkung. Kegiatan pertanian yang dilakukan sering terjadi masalah salah satunya dari organisme pengganggu tanaman (OPT).

Salah satu OPT yang sering merusak tanaman yang dibudidaya KWT Suka Maju adalah dari golongan hama. Hama merupakan salah satu OPT karena aktivitasnya dapat merusak tanaman dan menyebabkan kerugian pada tanaman. Selain itu, hama dalam arti sempit adalah semua hewan yang berpotensi mengganggu pada kegiatan budidaya tanaman yang berakibat merusak tanaman dan menurunkan produksi tanaman secara ekonomis (Wati et al., 2021). Serangan hama yang terjadi di pertanaman KWT Suka Maju sering dikendalikan menggunakan pestisida, terutama pestisida kimia. Penggunaan pestisida yang berkelanjutan akan mengakibatkan dampak negatif baikt terhadap lingkungan maupun hama. Dampak negatif penggunaan pestisida sintetis meliputi polusi lingkungan (kontaminasi tanah, air, dan udara), serangga hama menjadi resisten, resurgen maupun toleran terhadap pestisida, serta dampak negatif lainnya (Kardinan, 2011).

Selain pengendalian hama menggunakan pestisida, ada banyak teknik pengendalian hama yang merusak tanaman. Salah satu solusinya adalah penggunaan perangkap. Penggunaan perangkap serangga menggunakan atraktan atau perangkap kuning merupakan salah satu teknik pencuplikan serangga yang mulai banyak dipergunakan, baik dalam monitoring populasi (Priawandiputra \& Permana, 2016). Contoh perangkap yang sering digunakan adalah perangkap kuning. Menurut Yuliani \& Anggraeni (2020), perangkap kuning dengan perekat dapat menarik serangga untuk datang. Hama terutama serangga menggunakan sejumlah isyarat visual ataupun isyarat kimia (chemical cues) untuk menemukan inang berupa buah atau sayuran. Kesesuaian isyarat visual maupun isyarat kimia akan menyebabkan serangga lebih tertarik untuk menemukan inangnya. Ketertarikan serangga terhadap warna yang merupakan stimulus visual serta memberikan tanggapan tertentu terhadap serangga. Ketertarikan serangga lebih banyak terperangkap pada perangkap yang diberi warna kuning (Sunarno, 2011). Berdasarkan penelitian Amirulla dan Cheppy (2019 lihat Tarigan Ita et al., 2020), mengatakan setiap hari perangkap kuning dapat menangkap sekitat 46 ekor jantan dan betina lalat buah (Bactrocera sp). Selain itu, hasil penelitian Soraya et al. (2019) menunjukan bahwa penggunaan perangkap kuning mampu memerangkap lalat buah jantan dan lalat buah betina serta serangga-serangga lain.

$$
\text { Adanya kerusakan tanaman yang }
$$
disebabkan oleh hama sehingga diperlukan kegiatan pengabdian kepada masyarakan. Kegiatan ini bertujuan untuk mengenalkan teknik 
1323 Pelatihan Pembuatan Perangkap Serangga pada Kelompok Wanita Tani Suka Maju Kelurahan Malumbi - Yonce Melyanus Killa, Uska Peku Jawang, Marten Umbu Nganji, Lusia Danga Lewu, Melycorianda H. Ndapamuri, Suryani K. K. L. Kapoe

DOI: https://doi.org/10.31004/abdidas.v2i6.476

pengendalian hama terutama serangga yang ramah lingkungan dan menggunakan bahan bekas. Kiranya dengan kegiatan ini para anggota KWT Suka Maju dapat mempraktekkan dan menggunakan pengendalian menggunakan perangkap kuning di lahan budidaya mereka masing-masing.

\section{METODE}

\section{Alat dan bahan}

Alat yang digunakan dalam kegiatan ini adalah botol mineral bekas, kayu, kuas dan pisau. Sedangkan bahan yang digunakan berupa cat kuning dan lem tikus.

\section{Metode Pelaksanaan}

Adapun metode kegiatan pengabdian kepada masyarakat ini menggunakan pendekatan secara langsung meliputi survey lokasi, sosialisasi dan praktek. Adapun tahapan yang dilakuakan dalam pelaksanaan kegiatan ini meliputi:

\section{Survey lokasi}

Survey lokasi dilakukan untuk oleh TIM PKM Prodi Agroteknologi Universitas Kristen Wira Wacana Sumba. Kegiatan survey dilakukan dengan tujuan agar PKM tepat sasara dan sesuai dengan prioritas kebutuhan masyarakat. Kegiatan survey dilakukan pada tanggal 18 September 2021.

\section{Sosialisasi dan Ceramah}

Sosialisasi dilakukan pada tanggal 16 Oktober 2021. Tujuan sosialisasi dilakukan untuk memperkenalkan program pengabdian kepada masyarakat dan program studi Agroteknologi. Setelah melakukan sosialisasi, tim PKM langsung melakukan kegiatan menyampaikan materi tentang: (1) pengenalan hama-hama yang menyerang tanaman hortikultura terutama hamahama tanaman yang anggota KWT budidaya, (2) teknik pengendalian menggunakan perangkap kuning, (3) alat dan bahan yang digunakan untuk membuat perangkap kuning serta proses pembuatan perangkap kuning.

Praktek pembuatan perangkap kuning dan memasang perangkap di lahan

Praktek pembuatan perangkap kuning dilakukan guna melihat partisipasi dari anggota kelompok. Proses praktek yang dilakukan yaitu dengan mengecet botol bekas menggukan cat kuning dan mengoleskan lem tikus pada botol bekas yang telah dicat kuning. Setelah proses pembuatan perangkap kuning selasi, tim PKM beseta anggota kelompok melakukan pemasangan perangkap kuning di lahan budidaya.

\section{HASIL DAN PEMBAHASAN}

\section{Kegiatan Sosialisasi}

Kegiatan sosialisasi terlaksana di rumah ketua kelompok dan dihadiri oleh 20 yang terdiri dari anggota Kelompok Tani Wanita Suka Maju, ketua gapoktan, dosen-dosen dan mahasiswa prodi Agroteknologi. Kegiatan tersebut bertujuan untuk memberikan materi dan informasi mengenai apa itu Organisme Pengganggu Tanaman (OPT) baik itu dari patogen penyebab penyakit maupun hama. Selain memberikan informasi mengenai OPT, sosialisasi juga memberikan informasi mengenai teknik-teknik pengendalian yang dilakukan untuk mengendalikan OPT khususnya hama dan yang 
1324 Pelatihan Pembuatan Perangkap Serangga pada Kelompok Wanita Tani Suka Maju Kelurahan Malumbi - Yonce Melyanus Killa, Uska Peku Jawang, Marten Umbu Nganji, Lusia Danga Lewu, Melycorianda H. Ndapamuri, Suryani K. K. L. Kapoe

DOI: https://doi.org/10.31004/abdidas.v2i6.476

ditekankan adalah teknik pengendalian menggunakan perangkap kuning.

Sosialisasi selain mengenalkan OPT dan teknik pegendalian hama dengan menggunakan perangkap kuning, juga memberikan pelatihan tentang cara pembuatan perangkap kuning dari botol mineral bekas dan cat kuning. Dari peserta yang hadir, semuanya antusias dengan kegiatan pelatihan yang dilakukan dengan bertanya tentang keefektifan dari perangkap kuning dalam mengendalikan hama. Hasil sosialisasi menunjukan anggota kelompok tani paham dan dapat membedakan OPT dan dapat membuat perangkap kuning dari bahan bekas.

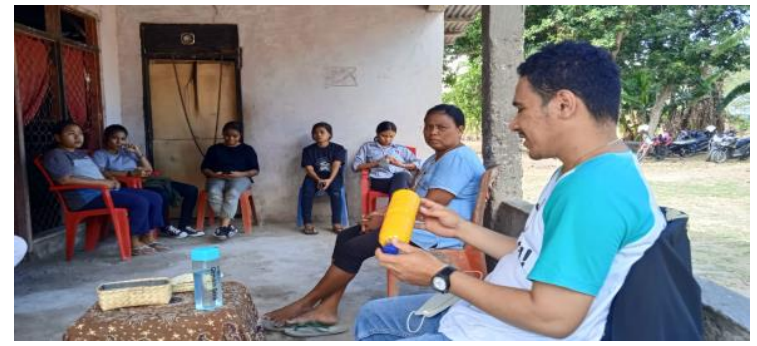

Gambar 1. Foto Sosialisasi Tentang Perangkap Kuning

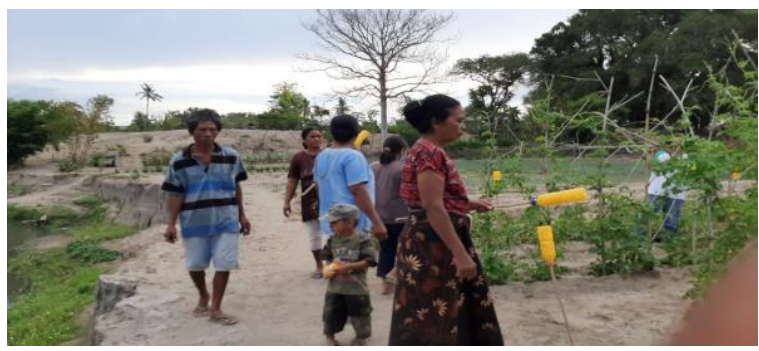

Gambar 2. Foto Pemasangan Perangkap Kuning Di Lahan

Pembuatan perangkap dilakukan setelah dilakukan sosialisasi. Pembuatan perangkap kuning menggunakan botol mineral bekas, kemudian dicat, dan dijemur pada matahari.
Setelah botol mineral yang telah dicat kuning kering, kemudian di olesi dengan lem tikus yang berfungsi untuk melekatkan hama (serangga) yang tertarik pada warna kuning. Setelah proses pengerjaan perangkap kuning, peserta langsung memasang perangkap tersebut di lahan pertanian yang terletak 200 meter dari lokasi sosialisasi.

Hasil dari kegiatan pembuatan perangkap menunjukan bahwa anggota kelompok mampu membuat perangkap kuning dan mengaplikasikan atau memasangnya pada lokasi lahan budidaya. Pembuatan dan pemasangan perangkap kuning sangat sederhana sehingga anggota kelompok tidak kesulitan dalam mengulangi pembuatan perangkap tersebut.

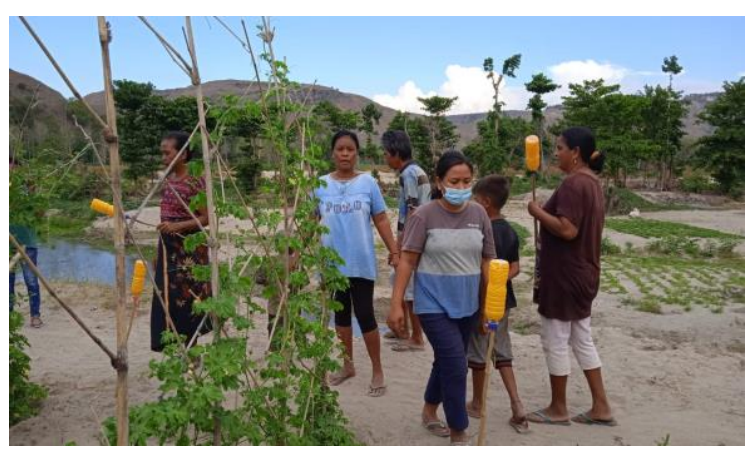

Gambar 3. Pemasangan Perangkap Kuning Di Lahan

\section{Monitoring Perangkap Kuning di Lahan Budidaya}

Kegiatan monitoring dilakukan setelah 1 minggu aplikasi perangkap kuning untuk melihat bagaimana perangkap kuning bejerja di lahan pertanaman. Dari hasil monitoring ditemukan beberapa serangga hama yang terperangkap pada perangkap kuning yang dipasang. Berdasarkan hasil monitoring ditemukan beberapa serangga 
1325 Pelatihan Pembuatan Perangkap Serangga pada Kelompok Wanita Tani Suka Maju Kelurahan Malumbi - Yonce Melyanus Killa, Uska Peku Jawang, Marten Umbu Nganji, Lusia Danga Lewu, Melycorianda H. Ndapamuri, Suryani K. K. L. Kapoe

DOI: https://doi.org/10.31004/abdidas.v2i6.476

yang terperangkap atau lengkep pada perangkap kuning seperti lalat buah (Bactrocera sp.) dan imago dari ulat crop (Plutella xylostela) serta beberapa serangga lain. Hal ini menunjukan bahwa peserta menyadari kegunaan perangkap kuning yang dibuat serta cara kerja dari perangkap tersebut.

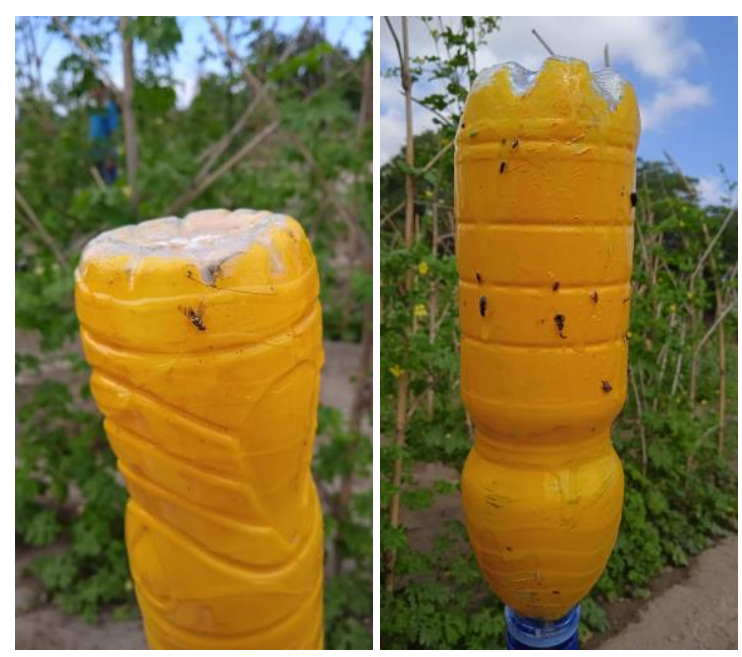

Gambar 4. Hasil Monitoring Perangkap Kuning Di Lahan

\section{SIMPULAN}

Pengabdian kepada Masyarakat yang dilakukan di Kelompok Wanita Tani (KWT) Suka Maju telah memberikan pengetahuan dan keterampilan baru terkait organisme pengganggu tanaman dan teknik pengendalian hama khususnya serangga menggunakan perangkap kuning yang dilakukan secara sederhana oleh setiap anggota KWT.

\section{UCAPAN TERIMA KASIH}

Penulis menyampaikan ucapan terimakasih kepada Rektor dan Lembaga Penelitian dan
Pengabdian Kepada Masyarakat (LPPM) Universitas Kristen Wira Wacana Sumba yang telah memberikan hibah internal untuk pelaksanaan kegiatan pengabdian kepada masyarakat.

\section{DAFTAR PUSTAKA}

Kardinan, A. (2011). Penggunaan Pestisida Nabati Sebagai Kearifan Lokal Dalam Pengendalian Hama Tanaman Menuju Sistem Pertanian Organik. Pengembangan Inovasi Pertanian, 4(4), 262-278.

Priawandiputra, W., \& Permana, Agus D. (2016). Efektifitas Empat Perangkap Serangga Dengan Tiga Jenis Atraktan Di Perkebunan Pala (Myristica Fragrans Houtt). Jurnal Sumberdaya Hayati, 1(2), 54-59. Https://Doi.Org/10.29244/Jsdh.1.2.54-59

Soraya, M., Marheni, \& Hasanuddin. (2019). Efektifitas Penggunaan Berbagai Perangkap Dengan Ketinggian Perangkap Yang Berbeda Terhadap Lalat Buah (Diptera:Tephritidae) Pada Tanaman Jeruk. Jurnal Agroekoteknologi Fp Usu, 7(2), 448-454. Https://Jurnal.Usu.Ac.Id/Agroekoteknologi44 8

Sunarno. (2011). Ketertarikan Serangga Hama Lalat Buah Terhadap Berbagai Papan Perangkap Berwarna Sebagai Salah Satu Teknik Pengendalian. Jurnal Agroforestri, $\mathrm{Vi}(2)$, 129-134. Https://Jurnalee.Files.Wordpress.Com/2012/1 2/

Tarigan Ita, S., Yowi Kuba Rambu, L., Djoh Andayani, D., Lena Veronika Varah, S., \& Malo Indri Mea, R. (2020). Penggunaan Perangkap Kuning Dan Pestisida Nabati Untuk Pengendalian Hama Tanaman Kubis Di Desa Kiritana, Kabupaten Sumba Timur. Jurnal Abdidas, 1(3), 761-769.

Wati, C., Arsi, A., Karenina, T., Riyanto, R., Nirwanto, Y., Nurcahya, I., Melani, D., Astuti, D., Septiarini, D., Purba, S. R. F., Ramdan, E. P., \& Nurul, D. (2021). Hama 
1326 Pelatihan Pembuatan Perangkap Serangga pada Kelompok Wanita Tani Suka Maju Kelurahan Malumbi - Yonce Melyanus Killa, Uska Peku Jawang, Marten Umbu Nganji, Lusia Danga Lewu, Melycorianda H. Ndapamuri, Suryani K. K. L. Kapoe

DOI: https://doi.org/10.31004/abdidas.v2i6.476

Dan Penyakit Tanaman. Yayasan Kita Menulis.

Yuliani, \& Anggraeni, A. R. (2020). Penggunaan Beberapa Perangkap Untuk Mengendalikan Hama Penggerek Batang Padi Pandanwangi (Oryza Sativa Var. Aromatic) Pada Fase Generatif. $\quad$ Pro-Stek, 1(1), 51. Https://Doi.Org/10.35194/Prs.V1i1.821 